\title{
中尾 章人
}

京都大学大学院工学研究科

助教

頸動脈小体における酸素センシング機構の解明

\section{§1. 研究成果の概要}

ヒトを含む好気性生物の生存において、体内の酸素センシングは必要不可欠である。頸動脈の 分岐点に存在する頸動脈小体が急性の酸素センシングを担うことはよく知られているが、その分子 メカニズムに関しては仮説が乱立しており混迷状態にある。本研究では TRP カチオンチャネルに 焦点を当て、急性の酸素センシングの新規分子メカニズムに迫る。これにより、永きに渡って続く論 争に決着をつけることを目指している。

本年度は、マウスから頸動脈小体を単離して細胞レベルで評価可能な実験系を確立し、カルシ ウムイメージングにて神経様細胞である glomus 細胞の高カリウム溶液による脱分極応答を確認し た。加えて頸動脈小体のアストロサイト様細胞である sustentacular 細胞の機能評価も可能とした。 TRP カチオンチャネルの中で酸素感受性を有する TRPA1 に着目し、免疫組織染色法を用いて 頸動脈小体における分布を評価した。in vivoの評価のため sustentacular 細胞のマーカーであ る GFAP のプロモーター下で Cre が発現するマウスと floxed TRPA1 マウスを掛け合わせて sustentacular 細胞特異的な TRPA1 欠損マウスを作製し、低酸素に対する呼吸適応の評価を行 った。加えて、急性の酸素センシングの分子メカニズムにさらに迫るため、マウス延髄呼吸中枢の アストロサイトの単離法を確立した。 